\title{
Does a sorghum-cowpea composite porridge hold promise for contributing to alleviating oxidative stress?
}

\author{
Franklin B. Apea-Bah ${ }^{\mathrm{a}, \mathrm{c}}$, Amanda Minnaar ${ }^{\mathrm{a}}$, Megan J. Bester ${ }^{\mathrm{b}}$, Kwaku G. Duodu ${ }^{\mathrm{a}}$ \\ ${ }^{a}$ Department of Food Science; Institute for Food, Nutrition and Well-being, University of Pretoria, Private Bag X20, \\ Hatfield 0028, Pretoria, South Africa; \\ ${ }^{b}$ Department of Anatomy, University of Pretoria, Prinshof Campus, Pretoria, South Africa; \\ ${ }^{c}$ Biotechnology and Nuclear Agriculture Research Institute, Ghana Atomic Energy Commission, P.O. Box LG 80, \\ Legon, Accra, Ghana. \\ *Corresponding author: Email address: gyebi.duodu@ up.ac.za; Tel: +27 12420 4299; Fax: +27 124202839 \\ Running title: Bioactive properties of sorghum-cowpea composite porridge
}

\begin{abstract}
The effect of compositing red non-tannin sorghum with cream-coloured cowpea and porridge preparation on phenolic profile and radical scavenging activity was studied. A maize-soybean composite porridge representing a similar product on the South African market was used as reference sample. UPLC-QToF-MS-ESI was used to determine phenolic composition of the grain flours, their composites and porridges. Total phenolic content was determined using FolinCiocalteu method while radical scavenging activity was determined using the ABTS, DPPH and NO radical scavenging assays. Four benzoic acid derivatives and five cinnamic acid derivatives were identified in the samples. The predominant flavonoid subclasses identified in sorghum were flavan-3-ols, flavanones and flavones while cowpea had mainly flavan-3-ols and flavonols with soybean having mainly isoflavones. Compositing the cereals with legumes significantly $(\mathrm{p}<0.01)$ increased their total flavonoid content and radical scavenging activities. Sorghum-cowpea composite porridge showed better promise in contributing to alleviating radical induced oxidative stress than maize-soybean composite porridge.
\end{abstract}

Keywords: Sorghum, cowpea, composite porridge, phenolic acids, flavonoids, radical scavenging activity. 


\section{Introduction}

Reactive oxygen and nitrogen species (ROS/RNS) are produced in large amounts by phagocytes in response to invading pathogens (Raso, Meli, Di Carlo, Pacilio, \& Di Carlo, 2001). An inefficient regulation of ROS/RNS can aggravate inflammatory processes leading to oxidative stress, damage to host cells (Leonarduzzi, Sottero, \& Poli, 2010) and damage to bioactive macromolecules such as DNA, proteins and lipids (Martindale \& Holbrook, 2002). Dietary phenolics such as phenolic acids, flavonoids and their glycosides have proven antioxidant activity (Awika, Rooney, Wu, Ronald, \& Cisneros-Zevallos, 2003) through their ability to donate hydrogen atoms that quench ROS/RNS. Their consumption therefore can lead to complementing the radical scavenging role of naturally occurring antioxidants such as glutathione in the body.

Sorghum is a good source of dietary phenolics (Awika \& Rooney, 2004) and indigenous to subSaharan Africa. In the semi-arid areas of the tropics and sub-tropics, sorghum appears to be more drought tolerant and able to grow well on many different soils compared to maize (Harris, 1976). It also has some disease and pest resistance attributed to its phenolics, prolamin protein and grain hardness (Chandrashekar \& Satyanarayana, 2006). In South Africa, maize-meal porridge (mealie-pap) is a staple food for a large segment of the population (Isaacson, 2005). Sorghum is consumed on a relatively smaller scale, mostly in the rural sector. With imminent climate change and its adverse effect on crop production especially in sub-Saharan Africa, there is the need to promote utilization of sorghum in such staple foods as porridge to ensure food security as well as promote health through the consumption of sorghum phenolics.

Cowpea is a grain legume indigenous to sub-Saharan Africa. It is a good source of dietary phenolics besides being a good dietary source of protein. The major flavonoids in sorghum are flavones, flavanones and 3-deoxyanthocyanidins (Dykes, Peterson, Rooney, \& Rooney, 2011). These flavonoids lack hydroxyl group at the $\mathrm{C} 3$ position in the $\mathrm{C}$-ring. The $\mathrm{C} 3$ - hydroxyl group, however, is present in the major cowpea flavonoids such as flavan-3-ols and flavonols (Duenas, Fernandez, Hernandez, Estrella, \& Muñoz, 2005). If sorghum and cowpea are combined in food preparation, it is anticipated that the resulting food product will have a good balance of dietary phenolics with enhanced antioxidant capacity that will contribute towards alleviating oxidative 
stress and inflammation resulting from overproduction of ROS/RNS. Apart from this the protein quality will also be enhanced (Jackson et al., 2013) which is important from a protein-energy malnutrition scenario. The objective of the current study therefore was to determine the effect of compositing sorghum with cowpea and cooking on phenolic profile and radical scavenging properties of a sorghum-cowpea composite porridge.

\section{Materials and methods}

\subsection{Materials}

A red non-tannin sorghum type (Buster, a Botswanan variety), a white maize hybrid (PAN 6043, grown in Vryburg, South Africa), a cream-coloured cowpea type (Bechuana white, supplied by Agricol, Potchefstroom, South Africa) and a defatted soybean sample obtained from a local supermarket were used in this work. Standard phenolic compounds, i.e. protocatechuic acid, vanillic acid, caffeic acid, 4-hydroxybenzoic acid, syringic acid, p-coumaric acid, ferulic acid, sinapic acid, chlorogenic acid, (+)-catechin, (-)-epicatechin, eriodictyol, eriodictyol 7-O- $\beta$-Dglucoside, quercetin dihydrate, luteolin, ( \pm )-naringenin, naringin, taxifolin, apigenin, kaempferol, kaempferol 3-O- $\beta$-D-glucoside, fisetin, rutin hydrate, genistin, daidzin, glycitin and coumestrol were purchased from Sigma-Aldrich. Methanol (univAR) and all other chemicals, unless stated otherwise, were purchased from Merck.

\subsection{Sample Preparation}

The sorghum, maize and cowpea grains were milled into flour using a hammer mill (Falling Number Laboratory Mill 3100, South Africa) to pass through a $250 \mu \mathrm{m}$ mesh. The flours were packed into zip-lock polyethylene bags and stored at $5^{\circ} \mathrm{C}$. Sorghum-cowpea and maize-soybean composite flours were prepared by mixing at a ratio of 70:30 of cereal to legume flour and stored at $5^{\circ} \mathrm{C}$. This cereal-to-legume ratio is recommended for correcting for lysine deficiency in maize (Ejigui, Savoie, Marin, \& Desrosiers, 2007).

\subsection{Porridge Preparation}

A modification of the porridge preparation procedure described by Kebakile (2008) was used. Four porridge samples were prepared comprising sorghum, maize, sorghum-cowpea and maizesoybean. The maize-soybean composite porridge was used as a reference sample and represented 
a similar product on the South African market. A $20 \%(\mathrm{w} / \mathrm{v})$ porridge was prepared by dispersing $160 \mathrm{~g}$ of flour in $400 \mathrm{ml}$ of distilled water and stirring for uniform mixing. It was then added to $400 \mathrm{ml}$ of boiling water and stirred continuously under low heat on a hotplate to prevent lump formation. It was allowed to simmer under low heat for $20 \mathrm{~min}$ with stirring at $2 \mathrm{~min}$ intervals. The cooked porridges were freeze dried, pulverized into powder form using a Waring blender, packed into polyethylene zip-lock bags and stored at $5^{\circ} \mathrm{C}$.

\subsection{Extraction of Free and Bound Phenolics}

A modification of the extraction procedure described by Krygier, Sosulski, and Hogge (1982) was used to prepare free (representing phenolic compounds potentially bioaccessible in the small intestine) and bound (representing phenolic compounds that could be released in the large intestine after colonic fermentation) phenolic extracts. For the free phenolics extraction, $1 \mathrm{~g}$ of each sample (flour or porridge) was extracted with $10 \mathrm{ml} 1 \%(\mathrm{v} / \mathrm{v}) \mathrm{HCl}$ - methanol solvent by magnetic stirring for $2 \mathrm{~h}$. After centrifugation (Rotanta 460R Hettiech, South Africa) at $1509 \times g$ for $10 \mathrm{~min}$ and separation of the supernatant, the residue was rinsed with four additional $10 \mathrm{ml}$ volumes of solvent min and centrifuged as above. The pooled supernatants were stored at $5^{\circ} \mathrm{C}$ in the dark until analysed. For the extraction of bound phenolics (saponified extracts), the residue was saponified with $20 \mathrm{ml} 2 \mathrm{~N} \mathrm{NaOH}$ for $4 \mathrm{~h}$ by magnetic stirring at room temperature. The $\mathrm{pH}$ of the saponified residue was adjusted to $2.0 \pm 0.2$ using conc. $\mathrm{HCl}$ and the reaction mixture centrifuged to remove a cloudy precipitate. The supernatant was extracted four times, each with $10 \mathrm{ml}$ diethyl ether: ethyl acetate (1:1). The organic phase was separated, dried with anhydrous sodium sulphate, filtered with Whatman No. 4 filter paper, evaporated to dryness under vacuum at $40^{\circ} \mathrm{C}$ with a rotary evaporator, re-dissolved in $20 \mathrm{ml} 1 \%(\mathrm{v} / \mathrm{v}) \mathrm{HCl}$ - methanol and stored at $5^{\circ} \mathrm{C}$ in the dark until analysed. For LC-MS analyses, $3 \mathrm{~g}$ of each sample was extracted three times with $10 \mathrm{ml} 1 \%(\mathrm{v} / \mathrm{v}) \mathrm{HCl}$ - methanol. The extracts were filtered with Whatman No. 4 filter paper and the filtrates were stored in amber glass vials at $5^{\circ} \mathrm{C}$ in the dark until analysed. All samples were extracted in duplicate.

\subsection{Profile of Phenolic Constituents}

The free and saponified phenolic extracts were filtered through $0.45 \mu \mathrm{m}$ Acrodisc PSF syringe filters (Pall Life Sciences, Ann Arbor MI, USA) prior to analyses. The chromatographic analyses 
were performed using a Waters Synapt G2 system comprising a Waters Acquity UltraPerformance Liquid Chromatograph (UPLC), equipped with a binary pump system (Waters, Milford, MA, USA). The UPLC system was coupled to a Quadrupole Time of Flight mass spectrometer (QToF-MS, Waters, Milford, MA, USA) using an electrospray ionization (ESI) source and a photodiode array (PDA) detector (Waters, Milford, MA, USA). Separation was done on a Waters BEH C18 (100 x $2.1 \mathrm{~mm}, 1.7 \mu \mathrm{m})$ reverse phase column. The mobile phase consisted of $0.1 \%(\mathrm{v} / \mathrm{v})$ aqueous formic acid (solvent $\mathrm{A}$ ) and $0.1 \%(\mathrm{v} / \mathrm{v})$ formic acid in acetonitrile (B). Gradient elution was done according to the following program: 100\% A from 0 to $22 \mathrm{~min}$; $72 \%$ A from 22 to $22.5 \mathrm{~min}$; $60 \%$ A from 22.5 to $23 \mathrm{~min}$; $0 \%$ A from 23 to $24.5 \mathrm{~min}$; $100 \%$ A from 24.5 to $26 \mathrm{~min}$. An injection volume of $3 \mu \mathrm{l}$ and a flow rate of $0.3 \mathrm{ml} / \mathrm{min}$ were used. Ionization was in negative mode with a capillary voltage of $3 \mathrm{kV}$ and cone voltage of $15 \mathrm{~V}$. Identification was done by comparing phenolic constituents in extracts with external phenolic acid and flavonoid standards as well as comparison of MS/MS fragmentation data and UV spectra with phenolic compounds reported in literature. Quantification was done by comparing integrated peak areas of phenolic compounds in extracts with that of the standards. Leucine enkaphelin (molecular weight $555 \mathrm{Da}$ ) was used as lock mass. Data were acquired using MassLynx v. 4.1 software (Waters, Milford, MA, USA).

\subsection{Total Phenolic Content}

The total phenolic content of the extracts was determined using a modification of the FolinCiocalteu procedure described byWaterhouse (2002). The volumes of all reagents were reduced to a quarter of what was reported by Waterhouse (2002) and incubation was done for 2 h. (+)Catechin was used as a standard and total phenolic content was expressed as milligram catechin equivalent per gram (mg CE/g) of flour or freeze-dried porridge, dry weight basis.

\section{7. $\quad$ ABTS $^{{ }^{+}}$Radical Scavenging Activity}

The $\mathrm{ABTS}^{\circ+}$ radical scavenging activity of the extracts was determined using the procedure described by Awika et al. (2003). Incubation of the ABTS stock solution was done for $12 \mathrm{~h}$ while the reaction mixture was incubated for $30 \mathrm{~min}$ and absorbance was read at $734 \mathrm{~nm}$. Trolox was used as a standard and results were expressed as micromole Trolox equivalents per gram sample ( $\mu \mathrm{mol} \mathrm{TE} / \mathrm{g})$, dry weight basis. 


\subsection{DPPH Radical Scavenging Activity}

The DPPH radical scavenging activity of the extracts was determined using a modification of the method described by Cheng, Moore, and Yu (2006). A $0.609 \mathrm{mM}$ DPPH stock solution was prepared in $80 \%(\mathrm{v} / \mathrm{v})$ aqueous methanol from which a $0.102 \mathrm{mM}$ working solution was prepared. A 5x dilution of the $1 \%$ (v/v) HCl-methanolic extract (10 $\mu \mathrm{l})$ was reacted with $190 \mu \mathrm{l}$ of DPPH working solution and incubated in the dark at room temperature $\left(15 \pm 2{ }^{\circ} \mathrm{C}\right)$ for $1 \mathrm{~h}$ in a 96-well plate. Absorbance was read at $570 \mathrm{~nm}$ using a microplate reader (Multiskan FC, Thermo Fisher Scientific, Shanghai, China). Trolox was used as a standard and results expressed as millimole Trolox equivalent per gram sample ( $\mathrm{mmol} \mathrm{TE} / \mathrm{g})$ dry weight basis.

\subsection{Nitric Oxide Radical Scavenging Activity}

The nitric oxide (NO) radical scavenging activity of the extracts was determined using a modification of the method described by Jagetia and Baliga (2004). The modification involved mixing $80 \mu \mathrm{l}$ volume of $5 \mathrm{mM}$ sodium nitroprusside in $0.2 \mathrm{M}$ phosphate buffered saline ( $\mathrm{pH}$ 7.4) with $20 \mu \mathrm{l}$ of a $10 \mathrm{x}$ aqueous dilution of the $1 \%$ (v/v) HCl-methanolic extract or Trolox $(0.39-$ $12.5 \mu \mathrm{M})$ and incubating in the dark at room temperature $\left(15 \pm 2^{\circ} \mathrm{C}\right)$ for $60 \mathrm{~min}$. A $100 \mu \mathrm{l}$ volume of Griess reagent (equal volumes of $0.33 \%(\mathrm{w} / \mathrm{v})$ sulphanilamide and $0.1 \%$ (w/v) naphthylethylenediamine dihydrochloride in $20 \%$ (v/v) glacial acetic acid) was added. The absorbance of the reaction mixture was measured at $570 \mathrm{~nm}$ using a microplate reader (Multiskan FC, Thermo Fisher Scientific, Shanghai, China). Percentage of NO scavenged by the extracts was expressed as $\mu \mathrm{mol}$ TE per gram dry weight basis).

\subsection{Statistical analysis}

Two-way analysis of variance was used to determine the effects of treatment and replication on response variables. Least significant difference test $(\mathrm{p}<0.05)$ was used for mean separation. Simple regression and correlation analyses were performed to determine the relationship between total phenolic content and radical scavenging activities. A two sample T-test was also used to compare observed means and expected means for radical scavenging activities of the cereal-legume composite flours. Statistica8 (StatSoft Inc, Tulsa, OK, USA) was used for statistical analysis. 


\section{Results and discussion}

\subsection{Phenolic composition of extracts from cereal and legume flours, their composites and porridges.}

The phenolic compounds were identified by comparing their retention times, UV-visible and mass spectral data with that of authentic standards (where available) and data from literature. Quantification of the phenolic compounds was done from regression equations developed from calibration curves plotted with authentic standards. The amino acid tryptophan was identified in soybean flour and the maize-soybean composite flour and porridge (Table 1). Tryptophan has been reported in cowpea (Ojwang, Yang, Dykes, \& Awika, 2013) but was not detected in the cream-coloured cowpea used in this study.

\subsubsection{Phenolic acids identified}

The phenolic acids identified (Table 1) were benzoic acid derivatives (protocatechuic acid, 4hydroxybenzoic acid, vanillic acid and syringic acid), cinnamic acid derivatives (caffeic acid, pcoumaric acid, sinapic acid and ferulic acid) and other derivatives of caffeic acid (chlorogenic acid, caffeoylglycerol and 1,3-dicaffeoylglycerol) and ferulic acid (ferulic acid hexoside). The acidified methanol extracts of all flours and porridges studied contained some benzoic acid and cinnamic acid derivatives. Ferulic acid was detected in the acidified methanol extracts of all flours and porridges. Caffeoylglycerol, 1,3-dicaffeoylglycerol and ferulic acid hexoside were only present in the acidified methanol extract from sorghum flour and porridge and the sorghumcowpea composite flour and porridge. Chlorogenic acid was detected only in soybean flour. For the saponified residues, ferulic acid was detected in all the flours and porridges except cowpea flour and soybean flour. Other phenolic acids were detected in the saponified residues of only a few samples. Syringic acid was only present in soybean flour, p-coumaric acid in maize porridge and maize-soybean flour and porridge and 4-hydroxybenzoic acid in sorghum porridge and sorghum-cowpea flour.

Most of the phenolic acids studied have also been reported in several sorghum cultivars (Awadelkareem, Muralikrishna, El Tinay, \& Mustafa, 2009; Hahn, Faubion, \& Rooney, 1983; N'Dri, Mazzeo, Zaupa, Ferracane, Fogliano, \& Pellegrini, 2012) and cowpea varieties (Cai, Hettiarachchy, \& Jalaluddin, 2003; Duenas et al., 2005). Phenolic acid profiles in sorghum differ 
among cultivars (Awadelkareem et al., 2009). Svensson, Sekwati-Monang, Lutz, Schieber, and Gänzle (2010) identified the glycerol esters caffeoylglycerol and 1,3-dicaffeoylglycerol in red sorghum. The combination of cereal flours and legume flours appeared to improve the phenolic acid profile of the cereal-legume composite flours and porridges due to the complementary roles of the cereal and legume flours. Sorghum contributed the cinnamic acid derivatives caffeoylglycerol, 1,3-dicaffeoylglycerol and ferulic acid hexoside to the sorghum-cowpea composite flour and porridge. Similarly, soybean contributed syringic acid and vanillic acid to the maize-soybean composite flour and porridge.

\subsubsection{Flavonoids identified}

All the flavonoids were identified in the acidified methanolic extracts but not in the saponified residue. Table 2 shows the flavan-3-ols, flavones and isoflavones identified in the samples. Flavan-3-ols and their glucosides were detected mainly in the cowpea flour and subsequently in the sorghum-cowpea composite flour and porridge. Flavan-3-ols and their glucosides have previously been reported in cowpea (Nderitu, Dykes, Awika, Minnaar, \& Duodu, 2013). The only flavan-3-ol detected in sorghum was (+)-catechin as previously reported in sorghum (Gupta \& Haslam, 1978). Flavones were detected mainly in the sorghum flour and porridge and subsequently in the sorghum-cowpea composite flour and porridge. Flavones are widely distributed in sorghum cultivars (Dykes et al., 2011). Apigenin was the only flavone detected in soybean flour and subsequently in the maize-soybean composite flour and porridge. Flavones and their glycosides have been reported in soybean pod (Boue, Carter-Wientjes, Shih, \& Cleveland, 2003). As expected, isoflavones were detected mainly in the soybean flour and subsequently in the maize-soybean composite flour and porridge. Soybean isoflavones have been reported to exist mainly in conjugated forms such as glucosides, acetyl glucosides or malonyl glucosides of the aglycones daidzein, glycetein and genistein (Wang \& Murphy, 1994). Shao, Duncan, Yang, Marcone, Rajcan, and Tsao (2009) reported that preparation of defatted soy flour from soybean seeds causes decarboxylation of malonyldaidzin and malonylgenistin to corresponding acetyldaidzin and acetylgenistin. This could explain why malonyldaidzin and malonylgenistin were not identified in the defatted soybean flour in the current study. The acetyl derivatives of the isoflavone glycosides were absent in the maize-soybean composite flour and porridge. 
Table 3 shows the flavonols, flavanones and flavanonol identified in the samples. All flavonols detected were identified in the cowpea flour and three flavonols (rutin, kaempferol-3-O- $\beta$-Dglucoside and kaempferol) were identified in soybean flour. The flavonols identified have been

previously reported in cowpea (Nderitu et al., 2013; Ojwang, Dykes, \& Awika, 2012). No flavonols were detected in the cereal flours and porridges. All composite flours and porridges contained some flavonols. Sorghum flour and porridge were the major sources of flavanones and this has been reported for several sorghum genotypes (Dykes, Seitz, Rooney, \& Rooney, 2009). Naringin was the only flavanone glycoside not detected in sorghum flour and porridge. The cowpea flour contained the flavanone glycosides naringin and eriodictyol-7-O- $\beta$-D-glucoside. Eriodictyol-7-O- $\beta$-D-glucoside was the only flavanone detected in maize flour. The flavanonol taxifolin was detected in the sorghum flour and porridge, the cowpea flour and subsequently in the sorghum-cowpea composite flour and porridge. It was also detected in soybean flour. Taxifolin has previously been reported in sorghum (Svensson et al., 2010) and cowpea (Salawu, Bester, \& Duodu, 2013). Cowpea was the major source of flavan-3-ols and their glucosides and flavonols and their glycosides while sorghum was the major source of flavones and flavanones in the sorghum-cowpea composite flour and porridge. Cowpea and sorghum flavonoids therefore complement each other to enhance the overall flavonoid profile of sorghum-cowpea composite flour and porridge. Similarly, soybean was the major source of flavone and isoflavones and their glucosides in the maize-soybean composite flour and porridge. This demonstrates an advantage of compositing cereals with legumes as both components contribute to an enhanced overall phenolic profile of the resultant cereal-legume composite flours and porridges.

\subsection{Effect of legume compositing and porridge preparation on phenolic acids content in cereal flours}

Cooking the sorghum flour into porridge did not significantly ( $\mathrm{p}>0.05)$ affect its protocatechuic acid content in the acidified methanol extract (Table 4). However, 4-hydroxybenzoic acid and cinnamic acid derivatives (caffeic, p-coumaric and ferulic acids) in the acidified methanol extract of sorghum flour were significantly higher $(\mathrm{p}<0.01)$ than in the porridge. This may be attributed to the phenolic acids probably forming complexes with proteins and other cell wall components on cooking, and thus becoming less extractable. Free extractable phenolic acids in cereals are 
present in the pericarp, testa and aleurone layer of the kernel (Dykes \& Rooney, 2006) from where they may interact with thermally denatured storage proteins in the cereal on cooking.

Phenolic compounds such as phenolic acids and flavonoids reportedly bind to proteins through non-covalent associations such as hydrophobic interactions (Liu, Qi, \& Li, 2010). However, the binding affinities of dietary phenolics for proteins are influenced by their structural differences and that of proteins (Xiao, Mao, Yang, Zhao, Zhang, \& Yamamoto, 2011). At high temperatures, however, covalent interactions between phenolics and proteins may occur (Prigent, Gruppen, Visser, van Koningsveld, de Jong, \& Voragen, 2003). When the sorghum flour was composited with $30 \%$ cowpea flour, the phenolic acid content either decreased or remained unchanged depending on the phenolic acid content of the cowpea. Cooking appeared not to have any consistent effect on the phenolic acid composition of sorghum-cowpea composite flour and maize flour. With the exception of protocatechuic acid and caffeic acid, defatted soybean had measurable amounts of all the phenolic acids and contributed substantially to the phenolic acid content of the maize-soybean composite flour and porridge. Cooking appeared to increase the extractability of most of the phenolic acids in the maize-soybean composite flour probably through cell wall disruption and solubilization.

Ferulic acid was the predominant bound phenolic acid released upon saponification of the residue from methanolic extraction. This has also been reported in sorghum (Hahn et al., 1983) and other cereals including maize (Adom \& Liu, 2002). It was, however, absent in the legume flours in the bound form. While cooking had no effect on sorghum bound ferulic acid content, that of maize increased by $131 \%$, probably due to disruption of cell wall components thereby enhancing release of bound or esterified ferulic acids in maize (Guo \& Beta, 2013). Sorghum bound ferulic acid released on cooking may have interacted with sorghum proteins (Knudsen, Munck, \& Eggum, 1988) thereby reducing their extractability. The maize-soybean composite flour and porridge had significantly $(\mathrm{p}<0.01)$ higher total phenolic acid content than the corresponding sorghum-cowpea composite flour and porridge probably due to the high total phenolic acid content of soybean. 


\subsection{Effect of legume compositing and porridge preparation on flavonoids content in cereal flours}

Fifteen flavonoids in the flours and porridges were quantified (Table 5). Compositing sorghum flour with cowpea flour and maize flour with defatted soybean flour increased the total flavonoids content of the composite flours compared to the cereal flours on their own. Again, this demonstrates the advantage of compositing cereals with legumes in flour preparation with regard to phenolic content.

Cooking of the flours into porridge reduced the total flavonoids content of the sorghum flour by $29 \%$, the sorghum-cowpea composite flour by $39 \%$ and the maize-soybean composite flour by $13 \%$. All the flavan-3-ols and flavanones in the maize, sorghum and sorghum-cowpea composite flours became less extractable on cooking the flours into porridges, probably due to phenolic interactions with components such as proteins. In the maize-soybean composite flour, the isoflavone glucosides were less extractable on porridge preparation. The flavonols content in the cereal-legume composite flours appeared not to be affected by porridge preparation. Among the cereals, sorghum flour and porridge had significantly $(\mathrm{p}<0.01)$ higher overall flavonoid content than corresponding maize flour and porridge while among the legumes, soybean flour had significantly $(\mathrm{p}<0.01)$ higher overall flavonoid content than cowpea flour.

\subsection{Effect of legume compositing and porridge preparation on total phenolic content and radical scavenging activity of cereal flours}

The total phenolic content and radical scavenging activities of the extracts are shown in Table 6. Generally, cooking appeared not to affect total phenolic content and radical scavenging activities of the cereal flours except for the DPPH radical scavenging activity of the sorghum flour acidified methanolic extract and saponified residue which reduced on cooking. For the sorghumcowpea composite, however, cooking of the flour into porridge caused a reduction in the total phenolic content and ABTS and DPPH radical scavenging activities of the acidified methanol extract. The ABTS and DPPH radical scavenging activities of the saponified residue of the sorghum-cowpea composite flour also reduced on porridge preparation while the total phenolic content remained unchanged. As explained earlier, the reduction may be attributed to phenolic 
interaction with other components such as proteins. Although the sorghum-cowpea composite porridge had lower total extractable phenolic content and radical scavenging activities than its flour, the composite porridge retained substantial radical scavenging activity. Cooking had no effect on the total phenolic content and radical scavenging activities of the maize-soybean composite flour. It is worth noting that the NO scavenging activity of both the sorghum-cowpea and maize-soybean composite flours were unaffected by cooking. NO is a physiological marker of oxidative stress and the observed scavenging activity of NO by sorghum-cowpea and maizesoybean composite flours and porridges demonstrate their potential in contributing to alleviating radical-induced oxidative stress in a physiological system.

Compositing of the cereal flours with legume flours significantly $(\mathrm{p}<0.01)$ increased the total phenolic content and all radical scavenging activities of the acidified methanol extracts of sorghum but increased only the $\mathrm{ABTS}^{\circ+}$ scavenging activity of maize acidified methanol extracts. The increase was due to the relatively higher total phenolic contents and radical scavenging activities of the acidified methanol extracts of the legumes compared to the cereals. Observed means of the cereal-legume composite flours were compared with calculated expected means to determine effect of cereal and legume compositing on radical scavenging activities. The expected means of radical scavenging activities were calculated based on the ratios of the individual (cereal and legume) components in the composite flour and their corresponding scavenging activities. The effect was described as additive (Ad) when no significant difference existed between observed and expected means and antagonistic (An) when the expected mean was significantly $(\mathrm{p}<0.05)$ higher than observed mean (Wang, Meckling, Marcone, Kakuda, \& Tsao, 2011). Compositing the cereal flours with legume flours produced an additive effect on both the total trolox equivalent antioxidant capacity and total DPPH radical scavenging activity (sum of free and bound radical scavenging activities) for both sorghum-cowpea and maizesoybean composite flours. While compositing sorghum flour with cowpea flour produced an additive effect on NO radical scavenging activity, compositing maize flour with soybean flour caused an antagonistic effect. This suggests that the sorghum-cowpea composite flour has a better potential to scavenge the NO radical than the maize-soybean composite flour. There was strong positive correlation between overall total phenolic content (sum of free and bound total 
phenolics content) and total trolox equivalent antioxidant capacity $(\mathrm{r}=0.96, \mathrm{p}<0.01)$ as well as total DPPH radical scavenging activity $(\mathrm{r}=0.96, \mathrm{p}<0.01)$, and a moderate relationship $(\mathrm{r}=0.62$, $\mathrm{p}<0.01)$ between overall total phenolic content and total NO radical scavenging activity.

Overall, the maize-soybean composite flour and porridge had higher total phenolic acids content (Table 4) and total flavonoids content (Table 5) than corresponding sorghum-cowpea composite flour and porridge essentially due to the rather high levels of phenolic acids and isoflavones in the soybean. It may therefore be expected that the maize-soybean composites would have higher total phenolic content and radical scavenging properties than the sorghum-cowpea composites. However, the sorghum-cowpea composite flour and porridge had significantly $(\mathrm{p}<0.01)$ higher total extractable phenolics content and radical scavenging activities than the maize-soybean composite flour and porridge (Table 6). This may be attributed to phenolic structure-antioxidant activity relationships. According to Rice-Evans, Miller, and Paganga (1996), the presence of 3hydroxyl group in the $\mathrm{C}$-ring, especially in the presence of unsaturation at the $\mathrm{C} 2-\mathrm{C} 3$ position in the flavonoid C-ring enhances radical scavenging activity since the 3-hydroxyl group donates hydrogen atoms to scavenge the radical while the $\mathrm{C} 2-\mathrm{C} 3$ unsaturation promotes electron delocalization of the resulting aryloxyl radical. The major flavonoids in cowpea (flavonols and flavan-3-ols) both have the 3-hydroxyl group in the C-ring, and flavonols further have the C2-C3 unsaturation, thereby enhancing their radical scavenging capacity. On the contrary, isoflavones which are the predominant soybean flavonoids, lack the C-ring 3-hydroxyl group which is vital for donating hydrogen atoms and thus have a lower radical scavenging activity than cowpea (Table 6). The sorghum-cowpea composite flour and porridge therefore have potentially better capacity to contribute towards alleviating radical induced oxidative stress than the maizesoybean composite flour and porridge.

\section{Conclusion}

The study shows that cooking has varying effects on phenolic acids and flavonoids in cereals, depending on the type and cereal source. Generally, extractable benzoic acid derivatives are more stable to cooking than extractable cinnamic acid derivatives. Flavanones and flavones are the predominant flavonoids in red non-tannin sorghum while flavan-3-ols and flavonols are the 
predominant flavonoids in cowpea. This indicates that sorghum and cowpea can complement each other with regard to flavonoid profile when used together in composite foods. Cooking has varying effects on cereal-legume composite flours depending on the stability of the component flavonoids. The cereal-legume composite porridges studied demonstrate potential to alleviate radical-induced oxidative stress through different radical scavenging mechanisms. The sorghumcowpea composite porridge has a better potential to scavenge the physiologically relevant nitric oxide radical than the maize-soybean composite porridge. The sorghum-cowpea composite porridge therefore shows better promise in contributing to alleviating free radical induced oxidative stress than the maize-soybean composite porridge.

\section{References}

Adom, K. K., \& Liu, R. H. (2002). Antioxidant activity of grains. Journal of Agricultural and Food Chemistry, 50(21), 6182-6187.

Awadelkareem, A. M., Muralikrishna, G., El Tinay, A., \& Mustafa, A. (2009). Characterization of tannin and study of in vitro protein digestibility and mineral profile of Sudanese and Indian sorghum cultivars. Pakistan Journal of Nutrition, 8(4), 469-476.

Awika, J. M., \& Rooney, L. W. (2004). Sorghum phytochemicals and their potential impact on human health. Phytochemistry, 65(9), 1199-1221.

Awika, J. M., Rooney, L. W., Wu, X., Ronald, L., \& Cisneros-Zevallos, L. (2003). Screening methods to measure antioxidant activity of sorghum (Sorghum bicolor) and sorghum products. Journal of Agricultural and Food Chemistry, 51(23), 6657-6662.

Boue, S. M., Carter-Wientjes, C. H., Shih, B. Y., \& Cleveland, T. E. (2003). Identification of flavone aglycones and glycosides in soybean pods by liquid chromatography-tandem mass spectrometry. Journal of Chromatography A, 991(1), 61-68.

Cai, R., Hettiarachchy, N., \& Jalaluddin, M. (2003). High-performance liquid chromatography determination of phenolic constituents in 17 varieties of cowpeas. Journal of Agricultural and Food Chemistry, 51(6), 1623-1627.

Chandrashekar, A., \& Satyanarayana, K. (2006). Disease and pest resistance in grains of sorghum and millets. Journal of Cereal Science, 44(3), 287-304.

Cheng, Z., Moore, J., \& Yu, L. (2006). High-throughput relative DPPH radical scavenging capacity assay. Journal of Agricultural and Food Chemistry, 54(20), 7429-7436.

Duenas, M., Fernandez, D., Hernandez, T., Estrella, I., \& Muñoz, R. (2005). Bioactive phenolic compounds of cowpeas (Vigna sinensis L). Modifications by fermentation with natural microflora and with Lactobacillus plantarum ATCC 14917. Journal of the Science of Food and Agriculture, 85(2), 297304.

Dykes, L., Peterson, G. C., Rooney, W. L., \& Rooney, L. W. (2011). Flavonoid composition of lemon-yellow sorghum genotypes. Food Chemistry, 128(1), 173-179.

Dykes, L., \& Rooney, L. W. (2006). Sorghum and millet phenols and antioxidants. Journal of Cereal Science, 44(3), 236-251. 
Dykes, L., Seitz, L. M., Rooney, W. L., \& Rooney, L. W. (2009). Flavonoid composition of red sorghum genotypes. Food Chemistry, 116(1), 313-317.

Ejigui, J., Savoie, L., Marin, J., \& Desrosiers, T. (2007). Improvement of the nutritional quality of a traditional complementary porridge made of fermented yellow maize (Zea mays): Effect of maize-legume combinations and traditional processing methods. Food and Nutrition Bulletin, 28(1), 23-34.

Guo, W., \& Beta, T. (2013). Phenolic acid composition and antioxidant potential of insoluble and soluble dietary fibre extracts derived from select whole-grain cereals. Food Research International, 51(2), 518-525.

Gupta, R. K., \& Haslam, E. (1978). Plant proanthocyanidins. Part 5. Sorghum polyphenols. Journal of the Chemical Society, Perkin Transactions 1, 4(8), 892-896.

Hahn, D., Faubion, J., \& Rooney, L. (1983). Sorghum phenolic acids, their high performance liquid chromatography separation and their relation to fungal resistance. Cereal Chemistry, 60(4), 255259.

Harris, K. (1976). The sorghum midge. Annals of Applied Biology, 84(1), 114-118.

Isaacson, C. (2005). The change of the staple diet of black South Africans from sorghum to maize (corn) is the cause of the epidemic of squamous carcinoma of the oesophagus. Medical Hypotheses, 64(3), 658-660.

Jackson, J. C., Weatherspoon, L., Nnyepi, M., Malete, L., Mokgatlhe, L., Lyoka, P., \& Bennink, M. (2013). Sorghum bean composite porridge nutritional quality and acceptability. Nutrition and Food Science, 43(5), 453-461.

Jagetia, G. C., \& Baliga, M. S. (2004). The evaluation of nitric oxide scavenging activity of certain Indian medicinal plants in vitro: a preliminary study. Journal of Medicinal Food, 7(3), 343-348.

Kebakile, M. M. (2008). Sorghum dry-milling processes and their influence on meal and porridge quality. PhD Thesis, University of Pretoria, South Africa.

Knudsen, K., Munck, L., \& Eggum, B. (1988). Effect of cooking, pH and polyphenol level on carbohydrate composition and nutritional quality of a sorghum (Sorghum bicolor (L.) Moench) food, ugali. British Journal of Nutrition, 59(01), 31-47.

Krygier, K., Sosulski, F., \& Hogge, L. (1982). Free, esterified, and insoluble-bound phenolic acids. 1. Extraction and purification procedure. Journal of Agricultural and Food Chemistry, 30(2), 330334.

Leonarduzzi, G., Sottero, B., \& Poli, G. (2010). Targeting tissue oxidative damage by means of cell signaling modulators: the antioxidant concept revisited. Pharmacology and Therapeutics, 128(2), 336-374.

Liu, E.-H., Qi, L.-W., \& Li, P. (2010). Structural relationship and binding mechanisms of five flavonoids with bovine serum albumin. Molecules, 15(12), 9092-9103.

Martindale, J. L., \& Holbrook, N. J. (2002). Cellular response to oxidative stress: Signaling for suicide and survival. Journal of Cellular Physiology, 192(1), 1-15.

N'Dri, D., Mazzeo, T., Zaupa, M., Ferracane, R., Fogliano, V., \& Pellegrini, N. (2012). Effect of cooking on the total antioxidant capacity and phenolic profile of some whole-meal African cereals. Journal of the Science of Food and Agriculture, 93, 29-36.

Nderitu, A. M., Dykes, L., Awika, J. M., Minnaar, A., \& Duodu, K. G. (2013). Phenolic composition and inhibitory effect against oxidative DNA damage of cooked cowpeas as affected by simulated in vitro gastrointestinal digestion. Food Chemistry, 141(3), 1763-1771.

Ojwang, L. O., Dykes, L., \& Awika, J. M. (2012). Ultra Performance Liquid Chromatography-Tandem Quadrupole Mass Spectrometry Profiling of Anthocyanins and Flavonols in Cowpea (Vigna unguiculata) of Varying Genotypes. Journal of Agricultural and Food Chemistry, 60(14), 37353744. 
Ojwang, L. O., Yang, L., Dykes, L., \& Awika, J. (2013). Proanthocyanidin profile of cowpea (Vigna unguiculata) reveals catechin-O-glucoside as the dominant compound. Food Chemistry.

Prigent, S. V., Gruppen, H., Visser, A. J., van Koningsveld, G. A., de Jong, G. A., \& Voragen, A. G. (2003). Effects of non-covalent interactions with 5-O-caffeoylquinic acid (chlorogenic acid) on the heat denaturation and solubility of globular proteins. Journal of Agricultural and Food Chemistry, 51(17), 5088-5095.

Raso, G. M., Meli, R., Di Carlo, G., Pacilio, M., \& Di Carlo, R. (2001). Inhibition of inducible nitric oxide synthase and cyclooxygenase-2 expression by flavonoids in macrophage J774A. 1. Life Sciences, 68(8), 921-931.

Rice-Evans, C. A., Miller, N. J., \& Paganga, G. (1996). Structure-antioxidant activity relationships of flavonoids and phenolic acids. Free Radical Biology and Medicine, 20(7), 933-956.

Salawu, S. O., Bester, M. J., \& Duodu, K. G. (2013). Phenolic composition and bioactive properties of cell wall preparations and whole grains of selected cereals and legumes. Journal of Food Biochemistry, doi:10.1111/jfbc.12026, 1-11. doi: doi:10.1111/jfbc.12026

Shao, S., Duncan, A. M., Yang, R., Marcone, M. F., Rajcan, I., \& Tsao, R. (2009). Tracking isoflavones: From soybean to soy flour, soy protein isolates to functional soy bread. Journal of Functional Foods, 1(1), 119-127.

Svensson, L., Sekwati-Monang, B., Lutz, D. L., Schieber, A., \& Gänzle, M. G. (2010). Phenolic acids and flavonoids in nonfermented and fermented red sorghum (Sorghum bicolor (L.) Moench). Journal of Agricultural and Food Chemistry, 58(16), 9214-9220.

Wang, H.-j., \& Murphy, P. A. (1994). Isoflavone content in commercial soybean foods. Journal of Agricultural and Food Chemistry, 42(8), 1666-1673.

Wang, S., Meckling, K. A., Marcone, M. F., Kakuda, Y., \& Tsao, R. (2011). Synergistic, additive, and antagonistic effects of food mixtures on total antioxidant capacities. Journal of Agricultural and Food Chemistry, 59(3), 960-968.

Waterhouse, A. L. (2002). Determination of total phenolics. Current Protocols in Food Analytical Chemistry, I(1.1), I1.1.1-I1.1.8.

Xiao, J., Mao, F., Yang, F., Zhao, Y., Zhang, C., \& Yamamoto, K. (2011). Interaction of dietary polyphenols with bovine milk proteins: Molecular structure-affinity relationship and influencing bioactivity aspects. Molecular Nutrition and Food Research, 55(11), 1637-1645. 
Table 1: Retention time, UV-Visible absorption maxima and mass spectral characteristics of phenolic acids, their derivatives and tryptophan identified in extracts from cereal (sorghum and maize) flours, legume (cowpea and soybean) flours, their composites and porridges.

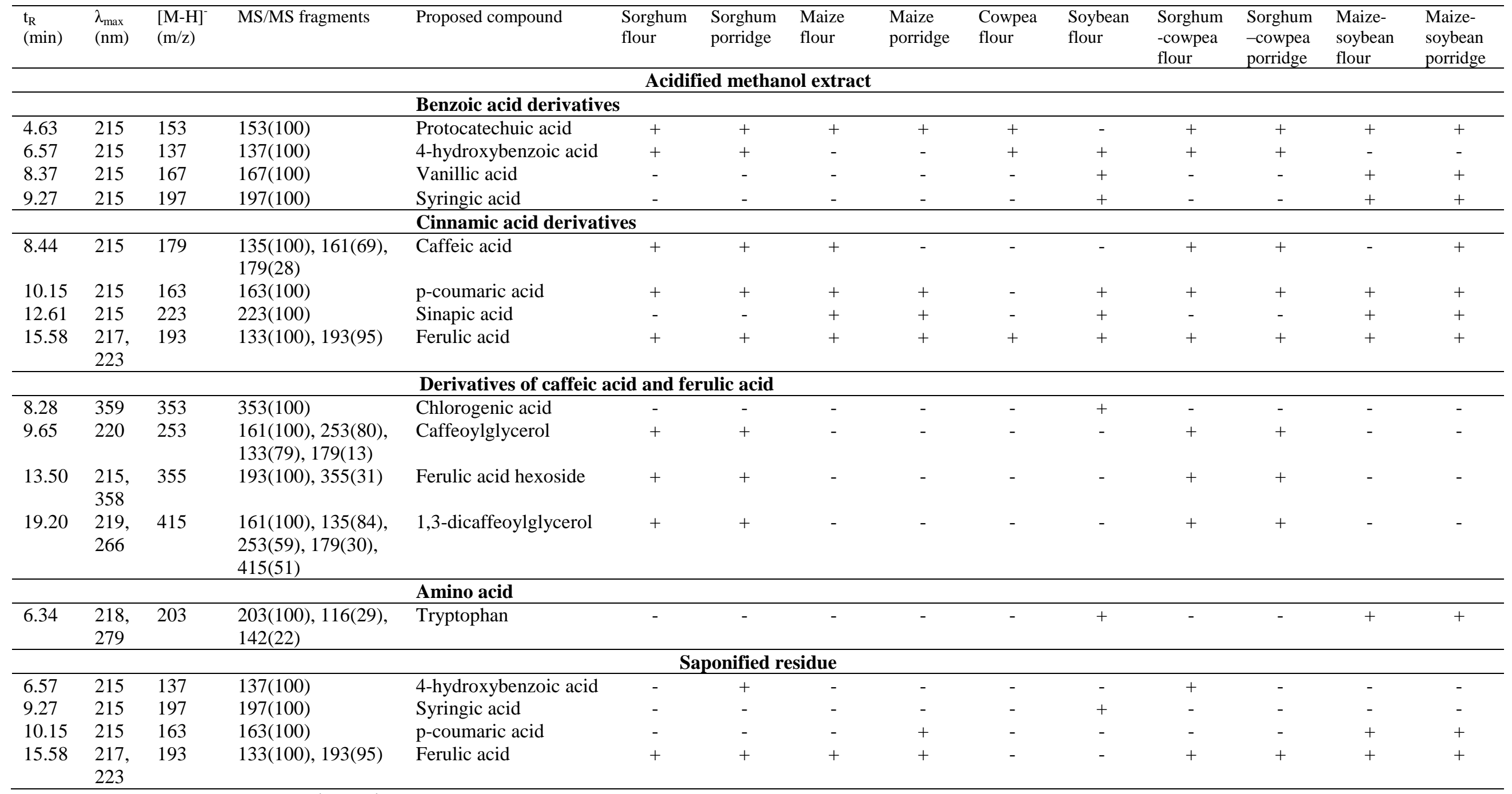

Key: + = present; - = not detected 
Table 2: Retention time, UV-Visible absorption maxima and mass spectral characteristics of flavan-3-ols, flavones and isoflavones identified in acidified methanolic extracts from cereal (sorghum and maize) flours, legume (cowpea and soybean) flours, their composites and porridges.

\begin{tabular}{|c|c|c|c|c|c|c|c|c|c|c|c|c|c|c|}
\hline $\begin{array}{l}t_{R} \\
(\min )\end{array}$ & $\begin{array}{l}\lambda_{\max } \\
(\mathrm{nm})\end{array}$ & $\begin{array}{l}{[\mathrm{M}-\mathrm{H}]^{-}} \\
(\mathrm{m} / \mathrm{z})\end{array}$ & $\begin{array}{l}\text { MS/MS fragments } \\
(\mathrm{m} / \mathrm{z})\end{array}$ & Proposed compound & $\begin{array}{l}\text { Sorghum } \\
\text { flour }\end{array}$ & $\begin{array}{l}\text { Sorghum } \\
\text { porridge }\end{array}$ & $\begin{array}{l}\text { Maize } \\
\text { flour }\end{array}$ & $\begin{array}{l}\text { Maize } \\
\text { porridge }\end{array}$ & $\begin{array}{l}\text { Cowpea } \\
\text { flour }\end{array}$ & $\begin{array}{l}\text { Soybean } \\
\text { flour }\end{array}$ & $\begin{array}{l}\text { Sorghum } \\
\text {-cowpea } \\
\text { flour }\end{array}$ & $\begin{array}{l}\text { Sorghum } \\
\text {-cowpea } \\
\text { porridge }\end{array}$ & $\begin{array}{l}\text { Maize- } \\
\text { soybean } \\
\text { flour }\end{array}$ & $\begin{array}{l}\text { Maize- } \\
\text { soybean } \\
\text { porridge }\end{array}$ \\
\hline & & & & Flavan-3-ols & & & & & & & & & & \\
\hline 6.28 & $\begin{array}{l}216 \\
278\end{array}$ & 451 & $289(100)$ & (+)-Catechin glucoside & - & - & - & - & + & - & + & + & - & - \\
\hline 7.87 & $\begin{array}{l}215 \\
273\end{array}$ & 289 & $\begin{array}{l}289(100), 245(31), \\
137(21)\end{array}$ & (+)-Catechin & + & - & - & - & + & - & + & + & - & - \\
\hline 8.21 & $\begin{array}{l}215 \\
278\end{array}$ & 451 & $289(100)$ & $\begin{array}{l}\text { (-)-Epicatechin } \\
\text { glucoside }\end{array}$ & - & - & - & - & + & - & + & + & - & - \\
\hline \multirow[t]{2}{*}{9.90} & 263 & 289 & $\begin{array}{l}289(100), 163(50), \\
137(39)\end{array}$ & (-)-Epicatechin & - & - & - & - & + & - & + & + & - & - \\
\hline & & & & Flavones & & & & & & & & & & \\
\hline 13.98 & $\begin{array}{l}219 \\
260\end{array}$ & 447 & $285(100), 447(61)$ & $\begin{array}{l}\text { Luteolin 7-O- } \beta-D- \\
\text { glucoside }\end{array}$ & + & + & - & - & - & - & + & + & - & - \\
\hline 19.02 & $\begin{array}{l}219 \\
266\end{array}$ & 285 & $285(100), 133(25)$ & Luteolin & + & + & - & - & - & - & + & + & - & - \\
\hline \multirow[t]{2}{*}{21.51} & $\begin{array}{l}216, \\
222, \\
260\end{array}$ & 269 & $\begin{array}{l}269(100), 117(37), \\
149(13)\end{array}$ & Apigenin & + & + & - & - & - & + & + & + & + & + \\
\hline & & & & Isoflavones & & & & & & & & & & \\
\hline 11.65 & $\begin{array}{l}215 \\
247\end{array}$ & 415 & $253(100), 415(23)$ & Daidzin & - & - & - & - & - & + & - & - & + & + \\
\hline 12.22 & $\begin{array}{l}295 \\
322\end{array}$ & $\begin{array}{l}491 \\
445\end{array}$ & $\begin{array}{l}283(100), 268(63), \\
445(38)\end{array}$ & Glycitin & - & - & - & - & - & + & - & - & + & + \\
\hline 13.99 & $\begin{array}{l}216 \\
259\end{array}$ & 431 & 269(100), 431(52) & Genistin & - & - & - & - & - & + & - & - & + & + \\
\hline 14.94 & $\begin{array}{l}215 \\
291\end{array}$ & 253 & $253(100)$ & Daidzein & - & - & - & - & - & + & - & - & + & - \\
\hline 16.68 & $\begin{array}{l}215 \\
249\end{array}$ & $\begin{array}{l}503 \\
457\end{array}$ & $253(100), 457(52)$ & 6"-O-acetyldaidzin & - & - & - & - & - & + & - & - & - & - \\
\hline 17.12 & $\begin{array}{l}263 \\
215\end{array}$ & 269 & $269(100)$ & Genistein & - & - & - & - & - & + & - & - & + & - \\
\hline 19.39 & $\begin{array}{l}259 \\
215\end{array}$ & $\begin{array}{l}519 \\
473\end{array}$ & 269 (100), 473(87) & 6"-O-acetylgenistin & - & - & - & - & - & + & - & - & - & - \\
\hline
\end{tabular}

Key: $\mathrm{t}_{\mathrm{R}}=$ retention time in minutes; $\lambda \max =$ wavelength at maximum absorption; $+=$ present; $-=$ not detected 
Table 3: Retention time, UV-Visible absorption maxima and mass spectral characteristics of flavonols, flavanonesandflavanonolidentified in acidified methanolic extracts from cereal (sorghum and maize) flours, legume (cowpea and soybean) flours, their composites and porridges.

\begin{tabular}{|c|c|c|c|c|c|c|c|c|c|c|c|c|c|c|}
\hline $\begin{array}{l}t_{R} \\
(\min )\end{array}$ & $\begin{array}{l}\lambda \max \\
(\mathrm{nm})\end{array}$ & $\begin{array}{l}{[\mathrm{M}-\mathrm{H}]^{-}} \\
(\mathrm{m} / \mathrm{z})\end{array}$ & MS/MS fragments & Proposed compound & $\begin{array}{l}\text { Sorghum } \\
\text { flour }\end{array}$ & $\begin{array}{l}\text { Sorghum } \\
\text { porridge }\end{array}$ & $\begin{array}{l}\text { Maize } \\
\text { flour }\end{array}$ & $\begin{array}{l}\text { Maize } \\
\text { porridge }\end{array}$ & $\begin{array}{l}\text { Cowpea } \\
\text { flour }\end{array}$ & $\begin{array}{l}\text { Soybean } \\
\text { flour }\end{array}$ & $\begin{array}{l}\text { Sorghum- } \\
\text { cowpea } \\
\text { flour }\end{array}$ & $\begin{array}{l}\text { Sorghum } \\
\text {-cowpea } \\
\text { porridge }\end{array}$ & $\begin{array}{l}\text { Maize- } \\
\text { soybean } \\
\text { flour }\end{array}$ & $\begin{array}{l}\text { Maize- } \\
\text { soybean } \\
\text { porridge }\end{array}$ \\
\hline & & & & Flavonols & & & & & & & & & & \\
\hline 11.81 & $\begin{array}{l}215 \\
350 \\
487\end{array}$ & 625 & $\begin{array}{l}300(100), 625(85), \\
301(50), 271(29)\end{array}$ & Quercetin 3-O-digalactoside & - & - & - & - & + & - & + & + & - & - \\
\hline 11.95 & $\begin{array}{l}215 \\
282\end{array}$ & 625 & $\begin{array}{l}300(100), 625(78), \\
301(60), 271(32)\end{array}$ & Quercetin 3-O-diglucoside & - & - & - & - & + & - & + & + & - & - \\
\hline 13.20 & $\begin{array}{l}217 \\
289 \\
330\end{array}$ & 609 & $\begin{array}{l}\text { 284(100), 285(48), } \\
609(62)\end{array}$ & Rutin & - & - & - & - & + & + & - & - & + & + \\
\hline 13.63 & $\begin{array}{l}324 \\
216\end{array}$ & 463 & $\begin{array}{l}300(100), 301(50), \\
463(71), 271(57), 255 \\
(37)\end{array}$ & Quercetin3-O-hexoside & - & - & - & - & + & - & + & + & - & - \\
\hline 15.00 & $\begin{array}{l}216 \\
317\end{array}$ & 447 & $285(100), 447(24)$ & $\begin{array}{l}\text { Kaempferol 3-O- } \beta \text {-D- } \\
\text { glucoside }\end{array}$ & - & - & - & - & + & + & - & - & + & + \\
\hline 18.95 & $\begin{array}{l}266 \\
215\end{array}$ & 301 & 301(100), 151(41) & Quercetin & - & - & - & - & + & - & + & + & - & - \\
\hline 20.34 & $\begin{array}{l}217 \\
323\end{array}$ & 317 & 268(100), 236(65) & Myricetin & - & - & - & - & + & - & + & + & - & - \\
\hline \multirow[t]{2}{*}{21.70} & 218 & 285 & $285(100)$ & Kaempferol & - & - & - & - & + & + & + & + & + & + \\
\hline & & & & Flavanones & & & & & & & & & & \\
\hline 13.50 & 450 & 449 & 287(100), 449(14) & $\begin{array}{l}\text { Eriodictyol 7-O- } \beta-\mathrm{D}- \\
\text { glucoside }\end{array}$ & + & + & + & - & + & - & + & + & + & + \\
\hline 15.81 & $\begin{array}{l}215 \\
279\end{array}$ & 579 & 197(100), 579(26) & Naringin & - & - & - & - & + & - & - & - & - & - \\
\hline 16.01 & $\begin{array}{l}215 \\
286\end{array}$ & 721 & $\begin{array}{l}\text { 433(100), 297(72), } \\
151(59), 405(45), \\
721(29), 559(21)\end{array}$ & $\begin{array}{l}5,7,3^{\prime}, 4^{\prime} \text {-tetrahydroxyflavan- } \\
5 \text {-O- } \beta \text {-galactosyl-4,8- } \\
\text { eriodictyol }\end{array}$ & + & + & - & - & - & - & + & + & - & - \\
\hline 17.10 & $\begin{array}{l}215 \\
282\end{array}$ & 721 & $\begin{array}{l}\text { 433(100), 297(64), } \\
\text { 151(40), 405(43), } \\
721(28), 559(20)\end{array}$ & $\begin{array}{l}5,7,3^{\prime}, 4^{\prime} \text {-tetrahydroxyflavan- } \\
5 \text {-O- } \beta \text {-glucosyl-4,8- } \\
\text { eriodictyol }\end{array}$ & + & + & - & - & - & - & + & + & - & - \\
\hline 18.27 & $\begin{array}{l}216 \\
260\end{array}$ & 287 & $\begin{array}{l}\text { 135(100), 151(62), } \\
287(43)\end{array}$ & Eriodictyol & + & + & - & - & - & - & + & + & - & - \\
\hline \multirow[t]{2}{*}{21.04} & $\begin{array}{l}259 \\
218\end{array}$ & 271 & $\begin{array}{l}271(100), 119(54), \\
151(37)\end{array}$ & $( \pm)$-Naringenin & + & + & - & - & - & - & + & + & - & - \\
\hline & & & & Flavanonol & & & & & & & & & & \\
\hline 12.68 & $\begin{array}{l}216, \\
312\end{array}$ & 303 & $125(100)$ & Taxifolin & + & + & - & - & + & + & + & + & - & - \\
\hline
\end{tabular}


Table 4. Phenolic acid content ( $\mu \mathrm{g} / \mathrm{g}$ sample dry weight basis) of extracts from cereal flours, legume flours, their composites and porridges.

\begin{tabular}{|c|c|c|c|c|c|c|c|c|c|c|}
\hline Sample & $\begin{array}{l}\text { Sorghum } \\
\text { flour }\end{array}$ & $\begin{array}{l}\text { Sorghum } \\
\text { porridge }\end{array}$ & Maize flour & $\begin{array}{l}\text { Maize } \\
\text { porridge }\end{array}$ & Cowpea flour & $\begin{array}{l}\text { Soybean } \\
\text { flour }\end{array}$ & $\begin{array}{l}\text { Sorghum- } \\
\text { cowpea } \\
\text { flour }\end{array}$ & $\begin{array}{l}\text { Sorghum- } \\
\text { cowpea } \\
\text { porridge }\end{array}$ & $\begin{array}{l}\text { Maize- } \\
\text { soybean flour }\end{array}$ & $\begin{array}{l}\text { Maize- } \\
\text { soybean } \\
\text { porridge }\end{array}$ \\
\hline \multicolumn{11}{|c|}{ Acidified methanol extract } \\
\hline $\begin{array}{l}\text { 4-hydroxybenzoic } \\
\text { acid }\end{array}$ & $264.1^{\mathrm{f}} \pm 16.2$ & $234.8^{\mathrm{e}} \pm 3.3$ & nd & nd & $99.4^{\mathrm{c}} \pm 7.1$ & $75.4^{\mathrm{b}} \pm 2.7$ & $207.8^{\mathrm{d}} \pm 2.8$ & $241.7^{\mathrm{e}} \pm 16.8$ & nd & $23.3^{\mathrm{a}} \pm 0.4$ \\
\hline Chlorogenic acid & nd & nd & nd & nd & nd & $36.6 \pm 4.3$ & nd & nd & nd & nd \\
\hline Vanillic acid & nd & nd & nd & nd & nd & $277.3 \pm 63.3$ & nd & nd & $170.4 \pm 11.0$ & $208.0 \pm 71.1$ \\
\hline Caffeic acid & $313.5^{\mathrm{e}} \pm 7.3$ & $117.5^{\mathrm{b}} \pm 10.3$ & $11.9^{\mathrm{a}} \pm 1.3$ & nd & nd & nd & $190.3^{\mathrm{d}} \pm 8.9$ & $152.1^{\mathrm{c}} \pm 4.3$ & nd & $12.9^{\mathrm{a}} \pm 2.0$ \\
\hline Syringic acid & nd & nd & nd & nd & nd & $401.1^{\mathrm{b}} \pm 26.6$ & nd & nd & $199.3^{\mathrm{a}} \pm 9.6$ & $208.6^{\mathrm{a}} \pm 17.8$ \\
\hline p-coumaric acid & $15.4^{\mathrm{d}} \pm 3.2$ & $2.4^{\mathrm{a}} \pm 0.4$ & $9.8^{\mathrm{c}} \pm 0.0$ & $4.1^{\mathrm{ab}} \pm 0.0$ & nd & $161.0^{\mathrm{g}} \pm 2.4$ & $10.3^{\mathrm{c}} \pm 2.7$ & $7.2^{\mathrm{bc}} \pm 0.2$ & $27.0^{\mathrm{e}} \pm 2.2$ & $50.6^{\mathrm{f}} \pm 1.0$ \\
\hline Sinapic acid & nd & nd & $9.7^{\mathrm{a}} \pm 2.9$ & $4.8^{\mathrm{a}} \pm 3.8$ & nd & $74.0^{\mathrm{c}} \pm 0.2$ & nd & nd & $18.1^{\mathrm{b}} \pm 2.1$ & $20.2^{\mathrm{b}} \pm 0.7$ \\
\hline Ferulic acid & $38.3^{\mathrm{c}} \pm 0.9$ & $19.5^{\mathrm{a}} \pm 0.4$ & $27.9^{\mathrm{ab}} \pm 0.2$ & $23.3^{\mathrm{a}} \pm 2.6$ & $22.3^{\mathrm{a}} \pm 0.7$ & $75.0^{\mathrm{e}} \pm 7.7$ & $27.4^{\mathrm{ab}} \pm 3.2$ & $24.6^{\mathrm{a}} \pm 4.2$ & $33.4^{\mathrm{bc}} \pm 0.3$ & $53.4^{\mathrm{d}} \pm 8.2$ \\
\hline $\begin{array}{l}\text { 4-hydroxybenzoic } \\
\text { acid }\end{array}$ & nd & $4.6 \pm 2.9$ & nd & nd & nd & nd & $3.9 \pm 1.6$ & nd & nd & nd \\
\hline Syringic acid & nd & nd & nd & nd & nd & $37.8 \pm 12.5$ & nd & nd & nd & nd \\
\hline p-coumaric acid & nd & nd & nd & $7.2^{\mathrm{b}} \pm 0.7$ & nd & nd & nd & nd & nd & nd \\
\hline Ferulic acid & $22.3^{\mathrm{ab}} \pm 12.4$ & $35.2^{\mathrm{abc}} \pm 3.3$ & $77.4^{\mathrm{bcd}} \pm 18.6$ & $178.9^{\mathrm{e}} \pm 32.5$ & nd & nd & $16.8^{\mathrm{a}} \pm 4.0$ & $14.7^{\mathrm{a}} \pm 0.4$ & $130.1^{\mathrm{de}} \pm 51.7$ & $84.0^{\mathrm{cd}} \pm 20.8$ \\
\hline $\begin{array}{l}\text { Total phenolic } \\
\text { acids }\end{array}$ & $688^{\mathrm{d}}$ & $447^{\mathrm{b}}$ & $149^{\mathrm{a}}$ & $229^{\mathrm{a}}$ & $155^{\mathrm{a}}$ & $1138^{\mathrm{e}}$ & $484^{\mathrm{b}}$ & $467^{\mathrm{b}}$ & $578^{\mathrm{c}}$ & $661^{\mathrm{cd}}$ \\
\hline
\end{tabular}

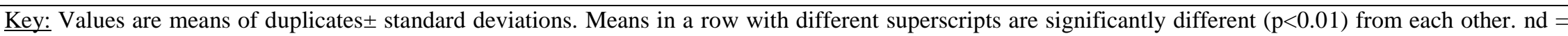
below limit of quantification. 
Table 5. Flavonoid content ( $\mu \mathrm{g} / \mathrm{g}$ sample dry weight basis) of acidified methanol extract from cereal flours, legume flours, their composites and porridges.

\begin{tabular}{|c|c|c|c|c|c|c|c|c|c|c|}
\hline Flavonoid & $\begin{array}{l}\text { Sorghum } \\
\text { flour }\end{array}$ & $\begin{array}{l}\text { Sorghum } \\
\text { porridge }\end{array}$ & Maize flour & $\begin{array}{l}\text { Maize } \\
\text { porridge }\end{array}$ & Cowpea flour & Soybean flour & $\begin{array}{l}\text { Sorghum- } \\
\text { cowpea flour }\end{array}$ & $\begin{array}{l}\text { Sorghum- } \\
\text { cowpea } \\
\text { porridge }\end{array}$ & $\begin{array}{l}\text { Maize-soybean } \\
\text { flour }\end{array}$ & $\begin{array}{l}\text { Maize-soybean } \\
\text { porridge }\end{array}$ \\
\hline Catechin & $17.5^{\mathrm{a}} \pm 2.3$ & nd & nd & nd & $10176.5^{\mathrm{d}} \pm 280.7$ & nd & $3004.6^{c} \pm 3.1$ & $1479.3^{\mathrm{b}} \pm 9.6$ & nd & nd \\
\hline Epicatechin & nd & nd & nd & nd & $771.7^{\mathrm{c}} \pm 17.4$ & nd & $236.3^{\mathrm{b}} \pm 3.6$ & $168.6^{\mathrm{a}} \pm 3.2$ & nd & nd \\
\hline Daidzin & nd & nd & nd & nd & nd & $9324.2^{\mathrm{c}} \pm 24.3$ & nd & nd & $6586.8^{\mathrm{b}} \pm 152.9$ & $5349.7^{\mathrm{a}} \pm 29.3$ \\
\hline Taxifolin & $40.1^{\mathrm{a}} \pm 2.1$ & $37.5^{\mathrm{a}} \pm 5.2$ & nd & nd & $448.8^{\mathrm{c}} \pm 1.8$ & nd & $170.7^{\mathrm{b}} \pm 16.3$ & $169.5^{\mathrm{b}} \pm 4.5$ & nd & nd \\
\hline Rutin & nd & nd & nd & nd & $31.0^{\mathrm{a}} \pm 8.2$ & $48.3^{\mathrm{b}} \pm 1.0$ & nd & nd & $20.4^{\mathrm{a}} \pm 2.3$ & $19.4^{\mathrm{a}} \pm 0.2$ \\
\hline $\begin{array}{l}\text { Eriodictyol 7- } \\
\text { O-glucoside }\end{array}$ & $71.0^{c} \pm 7.9$ & $38.5^{\mathrm{b}} \pm 8.2$ & $15.0^{\mathrm{a}} \pm 6.0$ & nd & $249.5^{\mathrm{e}} \pm 12.8$ & nd & $137.8^{\mathrm{d}} \pm 2.1$ & $69.9^{c} \pm 3.5$ & $26.4^{\mathrm{ab}} \pm 6.0$ & $30.3^{\mathrm{ab}} \pm 2.2$ \\
\hline Genistin & nd & nd & nd & nd & nd & $9679.6^{c} \pm 409.1$ & nd & nd & $7348.2^{\mathrm{b}} \pm 41.6$ & $6758.5^{\mathrm{a}} \pm 382.9$ \\
\hline $\begin{array}{l}\text { Kaempferol 3- } \\
\text { O-glucoside }\end{array}$ & nd & nd & nd & nd & $28.1 \pm 4.8$ & $16.6 \pm 1.7$ & nd & nd & $17.9 \pm 2.0$ & $14.1 \pm 4.1$ \\
\hline Naringin & nd & nd & nd & nd & $127.9 \pm 6.8$ & nd & nd & nd & nd & nd \\
\hline Eriodictyol & $904.9^{\mathrm{d}} \pm 8.4$ & $592.3^{\mathrm{c}} \pm 18.7$ & nd & nd & nd & nd & $516.2^{\mathrm{b}} \pm 12.7$ & $384.9^{\mathrm{a}} \pm 5.3$ & nd & nd \\
\hline Quercetin & nd & nd & nd & nd & $377.4^{\mathrm{b}} \pm 7.0$ & nd & $248.4^{\mathrm{a}} \pm 18.4$ & $207.5^{\mathrm{a}} \pm 5.1$ & nd & nd \\
\hline Luteolin & $164.7^{\mathrm{c}} \pm 2.0$ & $209.0^{\mathrm{d}} \pm 8.0$ & nd & nd & nd & nd & $90.6^{\mathrm{a}} \pm 2.5$ & $129.5^{\mathrm{b}} \pm 10.4$ & nd & nd \\
\hline Naringenin & $922.2^{\mathrm{d}} \pm 12.6$ & $619.1^{c} \pm 16.1$ & nd & nd & nd & nd & $532.7^{\mathrm{b}} \pm 4.4$ & $389.5^{\mathrm{a}} \pm 3.6$ & nd & nd \\
\hline Kaempferol & nd & nd & nd & nd & $15.6^{\mathrm{c}} \pm 1.9$ & $3.6^{\mathrm{a}} \pm 0.6$ & $10.4^{\mathrm{b}} \pm 1.0$ & $8.5^{\mathrm{b}} \pm 0.1$ & nd & nd \\
\hline $\begin{array}{l}\text { Total } \\
\text { flavonoids }\end{array}$ & $2253^{c}$ & $1600^{\mathrm{b}}$ & $15^{\mathrm{a}}$ & nd & $12226^{\mathrm{f}}$ & $19173^{\mathrm{h}}$ & $5014^{\mathrm{e}}$ & $3072^{\mathrm{d}}$ & $14000^{\mathrm{g}}$ & $12172^{f}$ \\
\hline
\end{tabular}

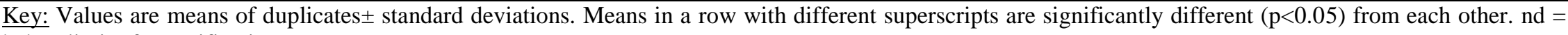
below limit of quantification. 
Table 6. Total phenolic content, TEAC, DPPH and NO radical scavenging activities of cereal flours, legume flours, their composites and porridges.

\begin{tabular}{|c|c|c|c|c|c|c|c|c|c|c|c|c|}
\hline Sample & $\begin{array}{l}\text { Sorghum } \\
\text { flour }\end{array}$ & $\begin{array}{l}\text { Sorghum } \\
\text { porridge }\end{array}$ & $\begin{array}{l}\text { Maize } \\
\text { flour }\end{array}$ & $\begin{array}{l}\text { Maize } \\
\text { porridge }\end{array}$ & $\begin{array}{l}\text { Cowpea } \\
\text { flour }\end{array}$ & $\begin{array}{l}\text { Soybean } \\
\text { flour }\end{array}$ & & $\begin{array}{l}\text { Sorghum- } \\
\text { cowpea flour }\end{array}$ & $\begin{array}{l}\text { Sorghum- } \\
\text { cowpea } \\
\text { porridge }\end{array}$ & & $\begin{array}{l}\text { Maize- soybean } \\
\text { flour }\end{array}$ & $\begin{array}{l}\text { Maize- } \\
\text { soybean } \\
\text { porridge }\end{array}$ \\
\hline \multicolumn{13}{|c|}{ Acidified methanol extract } \\
\hline TPC & $4.4^{\mathrm{b}} \pm 0.6$ & $3.8^{\mathrm{ab}} \pm 0.2$ & $3.0^{\mathrm{a}} \pm 0.0$ & $3.2^{\mathrm{a}} \pm 0.2$ & $14.9^{\mathrm{e}} \pm 1.2$ & $6.0^{\mathrm{c}} \pm 0.1$ & & $7.4^{\mathrm{d}} \pm 0.1$ & $5.5^{\mathrm{c}} \pm 0.3$ & & $3.8^{\mathrm{ab}} \pm 0.0$ & $3.8^{\mathrm{ab}} \pm 0.1$ \\
\hline TEAC & $20.3^{\mathrm{ab}} \pm 2.6$ & $17.1^{\mathrm{a}} \pm 0.2$ & $17.0^{\mathrm{a}} \pm 0.2$ & $12.1^{\mathrm{a}} \pm 0.1$ & $146.7^{\mathrm{e}} \pm 12.9$ & $63.1^{\mathrm{d}} \pm 1.2$ & & $66.2^{\mathrm{d}} \pm 7.5$ & $43.6^{\mathrm{c}} \pm 0.2$ & & $27.8^{\mathrm{b}} \pm 0.4$ & $27.4^{\mathrm{b}} \pm 2.2$ \\
\hline DPPH & $3.3^{\mathrm{b}} \pm 0.1$ & $2.2^{\mathrm{a}} \pm 0.4$ & $1.8^{\mathrm{a}} \pm 0.1$ & $1.5^{\mathrm{a}} \pm 0.3$ & $11.6^{\mathrm{d} \pm 0.7}$ & $1.9^{\mathrm{a}} \pm 0.3$ & & $5.9^{\mathrm{c}} \pm 0.8$ & $4.0^{\mathrm{b}} \pm 0.1$ & & $2.2^{\mathrm{a}} \pm 0.5$ & $1.5^{\mathrm{a}} \pm 0.1$ \\
\hline NO & $2.8^{\mathrm{d}} \pm 0.2$ & $2.7^{\mathrm{d}} \pm 0.1$ & $2.3^{\mathrm{cd}} \pm 0.2$ & $2.1^{\mathrm{c}} \pm 0.1$ & $5.1^{\mathrm{f}} \pm 0.2$ & $2.0^{\mathrm{bc}} \pm 0.0$ & & $3.6^{\mathrm{e}} \pm 0.0$ & $2.4^{\mathrm{cd}} \pm 0.1$ & & $1.3^{\mathrm{a}} \pm 0.0$ & $1.6^{\mathrm{ab}} \pm 0.0$ \\
\hline \multicolumn{13}{|c|}{ Saponified residue } \\
\hline TPC & $2.1^{\mathrm{c}} \pm 0.1$ & $1.9^{\mathrm{bc}} \pm 0.2$ & $3.7^{\mathrm{e}} \pm 0.1$ & $3.6^{\mathrm{e}} \pm 0.5$ & $1.0^{\mathrm{a}} \pm 0.2$ & $1.0^{\mathrm{a}} \pm 0.2$ & & $1.6^{\mathrm{b}} \pm 0.0$ & $1.5^{\mathrm{b}} \pm 0.0$ & & $2.9^{\mathrm{d}} \pm 0.1$ & $2.8^{\mathrm{d}} \pm 0.3$ \\
\hline TEAC & $10.5^{\mathrm{bc}} \pm 1.8$ & $9.2^{\mathrm{abc}} \pm 0.6$ & $22.3^{\mathrm{e}} \pm 0.5$ & $22.4^{\mathrm{e}} \pm 0.5$ & $9.4^{\mathrm{abc}} \pm 0.1$ & $6.5^{\mathrm{a}} \pm 0.5$ & & $11.4^{\mathrm{c}} \pm 0.4$ & $7.3^{\mathrm{ab}} \pm 0.2$ & & $16.0^{\mathrm{d}} \pm 2.0$ & $15.6^{\mathrm{d}} \pm 3.7$ \\
\hline DPPH & $2.3^{\mathrm{de}} \pm 0.2$ & $1.4^{\mathrm{ab}} \pm 0.3$ & $2.7^{\mathrm{e}} \pm 0.2$ & $2.0^{\mathrm{cd}} \pm 0.3$ & $2.3^{\mathrm{de}} \pm 0.3$ & $1.5^{\mathrm{abc}} \pm 0.2$ & & $2.0^{\mathrm{bcd}} \pm 0.1$ & $1.2^{\mathrm{a}} \pm 0.1$ & & $2.4^{\mathrm{de}} \pm 0.4$ & $2.0^{\mathrm{bcd}} \pm 0.4$ \\
\hline NO & $2.0^{\mathrm{b}} \pm 0.0$ & $2.2^{\mathrm{b}} \pm 0.1$ & $2.0^{\mathrm{b}} \pm 0.0$ & $2.3^{\mathrm{b}} \pm 0.0$ & $1.3^{\mathrm{a}} \pm 0.0$ & $2.1^{\mathrm{b}} \pm 0.2$ & & $1.1^{\mathrm{a}} \pm 0.1$ & $1.3^{\mathrm{a}} \pm 0.1$ & & $1.0^{\mathrm{a}} \pm 0.2$ & $1.2^{\mathrm{a}} \pm 0.1$ \\
\hline \multicolumn{13}{|c|}{ Total radical scavenging activities and cereal-legume flour interactive effects } \\
\hline \multirow[t]{2}{*}{ TEAC } & $30.7^{\mathrm{a}} \pm 0.8$ & & $39.4^{\mathrm{a}} \pm 0.3$ & & $156.2^{\mathrm{c}} \pm 13.0$ & $69.6^{\mathrm{b}} \pm 1.7$ & $\mathrm{O}$ & $77.6^{\mathrm{b}} \pm 7.9(\mathrm{Ad})$ & & $\mathrm{O}$ & $43.8^{\mathrm{a}} \pm 1.6(\mathrm{Ad})$ & \\
\hline & & & & & & & $\mathrm{E}$ & $68.4 \pm 4.4$ & & $\mathrm{E}$ & $48.4 \pm 0.3$ & \\
\hline \multirow[t]{2}{*}{ DPPH } & $5.6^{\mathrm{b}} \pm 0.3$ & & $4.5^{\mathrm{ab}} \pm 0.3$ & & $13.9^{\mathrm{d}} \pm 1.0$ & $3.4^{\mathrm{a}} \pm 0.1$ & $\mathrm{O}$ & $7.8^{\mathrm{c}} \pm 0.7(\mathrm{Ad})$ & & $\mathrm{O}$ & $4.6^{\mathrm{ab}} \pm 0.0(\mathrm{Ad})$ & \\
\hline & & & & & & & E & $8.1 \pm 0.1$ & & E & $4.2 \pm 0.2$ & \\
\hline \multirow[t]{2}{*}{ NO } & $4.8^{\mathrm{b}} \pm 0.4$ & & $4.3^{\mathrm{b}} \pm 0.3$ & & $6.4^{\mathrm{c}} \pm 0.4$ & $4.1^{\mathrm{b}} \pm 0.3$ & $\mathrm{O}$ & $4.7^{\mathrm{b}} \pm 0.2(\mathrm{Ad})$ & & $\mathrm{O}$ & $2.3^{\mathrm{a}} \pm 0.3(\mathrm{An})$ & \\
\hline & & & & & & & E & $5.3 \pm 0.1$ & & $\mathrm{E}$ & $4.2^{*} \pm 0.1$ & \\
\hline
\end{tabular}

Key: TPC-total phenolic content (mg CE/g sample dry basis); TEAC-trolox equivalent antioxidant capacity ( $\mu$ mol TE/g sample dry basis); DPPH- 2,2'-diphenyl1-picrylhydrazyl (mmol TE/g sample dry basis);NO- percent nitric oxide scavenged ( $\mu \mathrm{mol} \mathrm{TE} / \mathrm{g}$ sample dry basis); CE - catechin equivalents; TE - Trolox equivalents. O- observed value; E- expected value; Ad-additive effect; An- antagonistic effect $(*$ - $<<0.05)$. Values are means of duplicates \pm standard deviations Means in a row with different superscripts are significantly different $(\mathrm{p}<0.01)$ from each other. 